\title{
Passing of Dr. Irving I. Gottesman
}

\author{
Nancy L. Segal ${ }^{1}$
}

(C) Springer Science+Business Media New York 2016

It is with great sadness that I am alerting the membership to the loss of our esteemed colleague and personal friend, Dr. Irving I. Gottesman. Dr. Gottesman passed away on Wednesday, June 29, 2016, at the age of 85, at his home in Edina, Minnesota. He will be remembered as a pioneer in twin studies of psychopathology and personality, noted for his landmark book, Schizophrenia and genetics: A twin study vantage point (1972), co-authored with James Shields. Over the years and until his passing, Gottesman was a prolific investigator with over 300 papers and chapters, as well as presentations, on twin studies of personality, intelligence, psychopathology and epigenetics. Gottesman was also responsible for establishing the prestigious James Shields Lifetime Achievement Award for Twin Research.
A goal is to have his name added to the Wall of Honor of the Federation of Associations in Behavioral \& Brain Sciences (FABBS). In order to raise the required $\$ 2000$, please make a contribution by visiting the link, and be sure to include his name (Irving I. Gottesman) with the donation.

http://www.fabbs.org/fabbs-foundation/honoring-our-sci entists/make-a-donation/.

Nancy Segal will be organizing a symposium in Gottesman's name at the November 2017 meeting of ISTS in Madrid.

Note: A full obituary for Dr. Gottesman will be published in Behavior Genetics at a later date and a commemorative special issue of the journal is being organized by Matt McGue.
Nancy L. Segal

nsegal@fullerton.edu

1 Department of Psychology, California State University at Fullerton, Fullerton, CA, USA 